\title{
PENTINGNYA PENGUASAAN PSIKOLOGI BAGI PENYIDIK DALAM PEMERIKSAAN TERSANGKA PADA TAHAP PENYIDIKAN
}

(Suatu Tinjauan Yuridis dan Psikologi)

\author{
Siska Diana Sari*
}

\begin{abstract}
ABSTRAK
Tujuan penelitian ini adalah untuk mengetahui peranan penguasaan beberapa ilmu bantu dalam bidang hukum, khususnya dalam bidang psikologi bagi seorang penyidik. Hal ini dikarenakan penyidik mempunyai kesulitan untuk mendapatkan keterangan dari tersangak sehubungan dengan terjadinya suatu tindak pidana yang melibatkan tersangka. Tujuannya adalah guna menghindari adanya pemaksaan yang menyalahi hak asasi tersangka. Tujuan yang kedua adalah mendapatkan keterangan yang sebenarnya adalah karena kurangnya kemampuan para penyidik dalam teknik-teknik pemeriksaan tersangka. Penelitian dilakukan secara studi kepustakaan dan mencari data elektronik melalui internet. Data yang diteliti adalah pentingnya penguasaan ilmu psikologi bagi penyidik dalam proses pemeriksaan tersangka dalam tahap penyidikan di tingkat kepolisian,

Hasil penelitian memperlihatkan bahwa seorang penyidik dapat menerapkan salah satu bidang ilmu bantu dalam rangka penegakkan hukum, yaitu psikologi. Psikologi lebih berpijak pada pengetahuan tentang manusia, khusunya tentang perilaku dan perbuatan manusia dalam hubungannya dengan lingkungannya. Dengan dibantu psikologi, dapatlah seorang penyidik memperoleh atau "mengorek" keterangan dari tersangka dengan mudah, oleh karena telah dapat dilakukan pendekatan pribadi (personal approach) yang manusiawi. Dengan demikian dapat memperlancar pelaksanaan penyidikan sebagai langkah awal dalam proses pidana. Dalam kaitanya dengan hal tersebut yang perlu diusahakan adalah agar supaya jumlah tenaga psikologi jangan sampai kurang oleh karena penggunaan psikologi ini benar-benar dapat dirasakan manfaatnya. Dengan demikian penggunaan psikologi dalam pemeriksaan tersangka merupakan satu tahap langkah kemajuan bagi dunia penegak hukum. Jadi peranan psikologi dalam hukum mempunyai tujuan yang positif, yakni disamping untuk menjaga harkat dan martabat tersangka pada tingkat penyidikan, juga demi efektifitas pemeriksaan.
\end{abstract}

Kata kunci : psikologi, penyidik, penyidikan

* Siska Diana Sari adalah Dosen Program Studi PPKn Fakultas Pendidikan Ilmu Pendidikan Sosial IKIP PGRI Madiun 


\section{PENDAHULUAN}

Negara Indonesia adalah negara hukum, hal ini tertuang secara jelas dalam Pasal 1 ayat (3) UUD 1945 Perubahan Ketiga yang berbunyi "Negara Indonesia adalah Negara hukum". Artinya bahwa Negara Kesatuan Republik Indonesia adalah Negara yang berdasar atas hukum (Rechtsstaat), tidak berdasar atas kekuasaan (Machtsstaat) dan pemerintahan berdasarkan system konstitusi (hukum dasar), bukan absolutism (kekuasaan yang tidak terbatas). Konsekuensi dari Pasal 1 ayat (3) Amanademen Ketiga UUD 1945 ada 3 (tiga) prinsip dasar yang wajib dijunjung tinggi oleh setiap warga negara yaitu supremasi hukum, kesetaraan di hadapan hukum dan penegakan hukum dengan cara-cara yang tidak bertentangan dengan hukum (UUD 1945).

Upaya menjunjung tinggi hukum tersebut terwujud dalam perencanaan pembangunan di bidang hukum sebagaimana tercantum dalam Rencana Pembangunan Jangka Panjang Nasional (RPJMN)
2005-2025 yang tertuang dalam Undang-Undang No.17 Tahun 2007:

Bahwa khusus mengenai pembangunan hukum, diarahkan untuk mendukung terwujudnya pertumbuhan ekonomi yang berkelanjutan, mengatur permasalahan yang berkaitan dengan ekonomi, terutama dunia usaha dan dunia industry serta menciptakan iklim yang kondusif bagi investasi terutama penegakan dan perlindungan hukum. Lebih jauh, pembangunan hukum juga diarahkan untuk menghilangkan kemungkinan terjadinya tindak pidana korupsi serta mampu menangani dan menyelesaikan seara tuntas permasalahan yang terkait dengan kolusi, korupsi dan nepotisme (KKN). Untuk itu pembangunan hukum dilaksanakan melalui pembaruan materi hukum dengan tetap memperhatikan kemajemukan tatanan hukum yang berlaku dan pengaruh globalisasi sebagai upaya untuk meningkatkan kepastian dan perlindungan hukum, penegakan yang berintikan keadilan dan kebenaran, ketertiban dan kesejahteraan dalam rangka penyelenggaraan Negara yang makin tertib, teratur, lancar serta berdaya saing global. Sedangkan pembangunan bidang aparatur negara dilakukan melalui reformasi birokrasi 


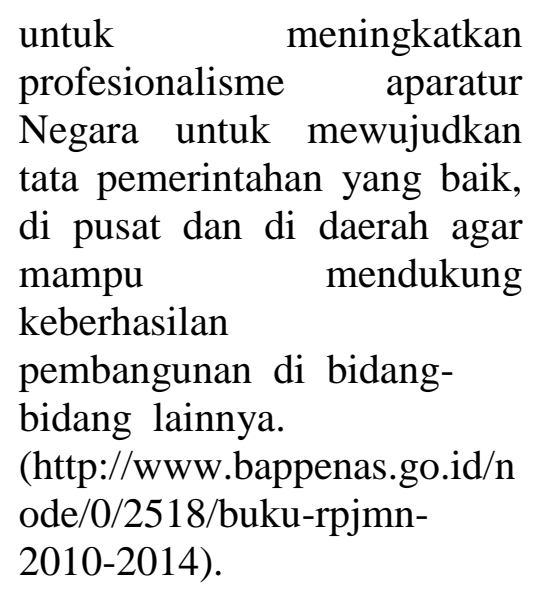

KUHAP tersebut sangat menjunjung tinggi, lebih memberi jaminan dan penghormatan terhadap harkat dan martabat manusia di mana tersangka dari tingkat pendahuluan yaitu pada tahap penyidikan sampai dengan tingkat terdakwa yaitu pada tahap pelaksanaan putusan hakim/pengadilan dijamin hak asasinya. Diharapkan, dengan berlakunya KUHAP tersebut kiranya dapat membantu seluruh lapisan masyarakat untuk menghayati hak dan kewajibannya serta untuk meningkatkan pembinaan sikap para pelaksana penegak hukum sesuai dengan fungsi dan wewenang masing masing kea rah tegaknya hukum, keadilan dan kepasian hukum. Di dalam KUHAP, disamping mengatur ketentuan tentang tata cara proses proses pidana juga mengatur tentang hak dan kewajiban seseorang yang terlibat proses pidana. Proses pidana yang dimaksud Penulis adalah tahap pemeriksaan tersangka (interogasi) pada tingkat penyidikan. Pemeriksaan tersangka merupakan salah satu usaha untuk pengumpulan bahan pembuktian, yaitu untuk mendapatkan keterangan/kejelasan tentang terjadinya sesuatu tindak pidana yang mungkin melibatkan tersangka. 
Pelaksanaan interogasi ini dilakukan oleh penyidik. Penyidiklah yang akan berperan di garis terdepan dalam pelaksanaan penegakan hukum, sehingga sangat perlu memperhitungkan akan terjadinya masalah - masalah yang tidak dapat dihindari dalam pelaksanaan KUHAP. Hal ini dikarenakan jiwa dan materi KUHAP sangat berbeda dengan Hukum Acara Pidana yang lama (HIR), di mana telah terjadi perubahan yang mendasar di dalam sistem peradilan pidana yang akan mempengaruhi pula system penyidikannya. Perubahan dalam bidang penyidikan yang dimaksud sebagai berikut ini (Departemen Kehakiman, 1982: 22 -23) :

\section{Diberlakukannya KUHAP} dengan segala perubahan didalam sistem penyidikan tersebut, menuntut adanya (Departemen Kehakiman, 1982: 23) :

“....peningkatan personal, peralatan, dana dan sarana - sarana lainnya baik kuantitatif maupun kualitatif, guna kepentingan pelaksanaan tugas Polri pada umunya, terutama pelaksanaan tugas reserse yang mengemban fungsi penyidikan berdasarkan KUHAP...”

Sikap emosional penyidik sering timbul pada tahap interograsi tersangka dengan beberapa kemungkinan, antara lain kemungkinan tersangka yang diperiksa bersikap lamban, sulit untuk dimintakan keterangan/informasi yang diperlukan sehubungan dengan tindak pidana yang terjadi. Di lain pihak, kemungkinan penyidik yang bertugas kurang dapat menyelami tingkah laku atau kepribadian tersangka sehingga akan mengalami kesulitan untuk mendapatkan keterangan yang diperlukan. Keadaan inilah yang kerap kali dapat menghambat kelancaran pemeriksaan. Terkadang kita masih mendengar masih ada penyidik yang memaksa tersangka agar mau mengakui kesalahan yang dituduhkan kepadanya sekalipun tuduhan itu tidak benar. Padahal sebenarnyalah penyidik dalam melakukan pemeriksaan, sebelum persoalannya di bawa ke penuntut umum dan ke pengadilan tidak dibenarkan memaksa tersangka agar 
mau mengaku salah kalau memang tersangka merasa tidak bersalah. Hal ini terbukti setelah persoalan sampai ke penuntut umumtersangka akan mencabut kembali pengakuannya yang pernah di ucapkan di hadapan penyidik dengan alasan "dipaksa" untuk mengaku. Kalau tidak mau harus siap menerima perlakuan kasar dari pihak penyidik (R.Soesilo, 1980: 21-22).

Perlu diingat bahwa tujuan Hukum Acara Pidana adalah untuk mencari dan mendapatkan atau setidak-tidaknya mendekati kebenaran materiil, ialah kebenaran yang selengkap-lengkapnya dari suatu perkara pidana dengan menerapkan ketentuan hukum acara pidana secara jujur dan tepatdengan tujuan untuk mencari siapakah pelaku yang dapat didakwakan melakukan suatu pelanggaran hukum melalui pemeriksaan dan proses peradilan. Jadi, selaras dengan tujuan hukum acara pidana tersebut perlu diusahakan keterangan yang sebenar-benarnya, sejujur-jujurnya dari tersangkatanpa adanya unsur paksaan yang dapat mewarnai/menodai kebenaran dari keterangan tersangka. Walau tak dapat dipungkiri, bahwasanya dalam penyidikan kebenaran yang mutlak $100 \%$ tidak akan dapat dicapai, karena hanya Tuhan-lah dalam hal ini yang mengetahuinya. Akan tetapi fakta -fakta bukti dapat ditemukan sebanyak - banyaknya sehingga dapat mendekati kebenaran yang menyakinkan bahwa ada suatu tindak pidana tertentu telah dilakukan dan siapakah orang yang telah berbuat (R. Soesilo, 1980: 21-22).

Sejak dini KUHAP sudah berusaha mencegah diadakannya/digunakannya kekerasan/upaya paksa, karena upaya paksa tersebut baru digunakan sebagai tindakan yang terpaksa dilakukan demi kepentingan umum yang lebih luas. Sebagaimana diketahui, seorang penyidik disamping bertugas pokok memeriksa tersangka juga mempunyai tugas/peranan lain yang lebih penting dipandang dari kepentingan nasional yang tersirat dari fungsi penyidik dalam tugas penyidikan. Tugas tambahan tersebut adalah dalam hubungannya dengan usaha mencegah dan memberantas 
kejahatan-kejahatan yang mungkin timbul dari berbagai kemajuan/perkembangan teknologi dewasa ini.

Bentuk pencegahan dan pemberantasan itu mungkin memerlukan bantuan ilmu-ilmu lainnya, baik untuk membuktikan kesalahan pelaku maupun untk permintaan pertanggungjawaban pelakunya, misalnya bantuan kedokteran kehakiman, kimia kehakiman, psikiatri forensik, psikologi dan sebagainya yang menyangkut tingkah laku manusia. Ini membuktikan keilmuan hukum saja khususnya hukum pidana tidak memadai untuk memberantas dan mencegah kejahatan. Dalam hal ini diperlukan bantuan ilmu lainnya.

Demi kelancaran tugas penyidikan, dituntut bagi setiap penyidik agar menguasai segi-segi teknis hukum dan ilmu-ilmu bantu lainnya dalam acara yang meliputi antara lain psikologi, kriminologi, antropologi, dan sebagainya. Khusus dalam pemeriksaan tersangka sangat diperlukan pemakaian psikologi untuk memperbaiki teknik-teknik pemeriksaan, dengan tujuan untuk meningkatkan keterampilan dan disiplin hukum demi penerapan hak asasi manusia.

Menyoroti peran psiklogi bila dikaitkan dengan pelaksanaan penegakan hukum di tingkat penyidikan, khususnya pada pemeriksaan tersangka adalah sangat tepat. Hal ini mengingat psikologi lebih melihat latar belakang, tingkah laku dan perbuatan tersangka dengan cara pendekatan kejiwaan, sehingga diharapkan dapat memperlancar tugas penginterogasian/pemeriksaan tersangka tanpa adanya suatu sikap paksaan/penekanan. Dengan demikian apa yang menjadi tujuan isi dan materi KUHAP yakni menjunjung tinggi harkat dan martabat manusia khususnya hak asasi tersangka dapat terwujud dengan baik.

Berdasarkan latar belakang di atas, dapat disimpulkan permasalahan dalam penulisan ini adalah sebagai berikut:

1. Perlu penguasaan beberapa ilmu bantu dalam bidang hukum, khususnya dalam bidang psikologi bagi seorang penyidik. Hal ini dikarenakan penyidik 
mempunyai kesulitan untuk mendapatkan keterangan dari tersangak sehubungan dengan terjadinya suatu tindak pidana yang melibatkan tersangka. Tujuannya adalah guna menghindari adanya pemaksaan yang menyalahi hak asasi tersangka.

2. Kesulitan unutk mendapatkan keterangan yang sebenarnya adalah karena kurangnya kemampuan para penyidik dalam teknik-teknik pemeiksaan tersangka.

Pengertian penyidik dalam KUHAP diatur dalam pasal 6 ayat (1) jo pasal 1 butir 1 KUHAP. Pasal 6 ayat (1) KUHAP berbunyi: (1). Penyidik adalah:

a. Pejabat Polisi Negara Republik Indonesia;

b. Pejabat Pegawai Negari Sipil tertentu yang diberi wewenang khusus oleh Undang-undang.

Pasal 1 butir 1 KUHAP berbunyi: Penyidik adalah Pejabat Polisi Negara Republik Indonesia atau Pejabat Pegawai Negeri Sipil tertentu yang diberi wewenang khusus oleh Undang-undang untuk melakukan penyidikan.

Adapun yang dimaksud dengan penyidikan sebagaimana ditetapkan dalam pasal 1 butir 2 KUHAP adalah: Penyidikan adalah serangkaian tindakan penyidik dalamUndang-undang ini untuk mencari serta mengumpulkan bukti yang mana dengan bukti itu membuat terang tindak pidana yang terjadidan gunaa menemukan tersangkanya (Andi Hamzah, 1990:121-122): Berdasarkan pasal 1 butir 2 jo pasal 6 ayat (1) KUHAP, ada dua badan yang dibebani wewenang penyidikan, yaitu:

a. Pejabat Polisi Negara Republik Indonesia;

b. Pejabat Pegawai Negari Sipil tertentu yang diberi wewenang khusus oleh Undang-undang.

Disamping tugas penyidik, Polisi juga dibebani tanggung jawab sebagai penyidik. Tugas penyidikan dan penyelidikan merupakan suatu kesatuan rangakain yang tak dapat dipisahkan dan saling menunjang, dilihat dari pengertian penyidikan dengan penyelidikan sebagaimana diatur dalam pasal 1 butir 4 jo pasal 
4 KUHAP adalah: "Pejabat Polisi Negara Republik Indonesia yang diberi wewenang oleh Undangundang ini untuk melakukan penyidikan".

Pengertian penyelidikan menurut pasal 1 butir 5 KUHAP adalah: Penyelidikan adalah serangkian tindakan penyelidik untuk mencari dan menemukan suatu peristiwa yang diduga sebagai tindak pidana guna menentukan dapat atau tidaknya dilakukan penyidikan menurut cara yang diatur dalam Undang-undang ini.

Disamping penyidik, dan penyelidik, dikenal pula penyidik pembantu, yang diatur dalam pasal 1 butir 3 jo pasal 10 ayat(1) KUHAP:

Pasal 1 butir 3 KUHAP berbunyi:

(1) Penyidik pembantu adalah Pejabat Kepolisian Negara Republik Indonesiayang diangkat oleh Kepala Kepolisian Negara Republik Indonesia berdasarkan syarat kepangkatan dalam ayat (2) pasal ini;

(2) Syarat kepangkatan sebagaimana tersebut pada ayat
(1) diatur dengan Peraturan Pemerintah.

Pasal 10 KUHAP berbunyi:

Penyidik pembantu adalah Pejabat Kepolisian Negara Republik Indonesia yang karena diberi wewenang tertentu dapat melakukan tugas penyidikan yang diatur dalam Undang-undang ini. Peranan penyidik pembantu tersebut diatur lebih lanjut dalam Pasal 3 Peraturan Pemerintah No. 27 tahun 1983 yang menentukan bahwa penyidik pembantu adalah: Pejabat Kepolisian Negara Republik Indonesia yang berpangkat Sersan dua Polisi dan Pejabat Pegawai Negara Sipil tertentu dalam lingkungan Kepolisian Negara atau usul komandan atau pimpinan kesatuan masing-masing.

\section{Polisi sebagai penyidik dan}

\section{wewenangnya}

Di dalam KUHAP, polisi ditempatkan sebagai penyidik utama dan tunggal (pasal 6 ayat (2) jo pasal 284 ayat KUHAP). Ketentuan ini sangat berbeda dengan ketentuan yang diatur dalam HIR, bahwa disamping Polisi sebagi penyidik 
juga jaksa ditentukan sebagai penyidik lanjutan. Tetapi bila melihat pada peraturan peralihan KUHAP (pasal 284 ayat (2) KUHAP), maka tugas jaksa sebagai penuntut umum dan sebagai penyidik masih tetap dan sama sekali tidak dikurangi yaitu tugas jaksa yang diatur dalam undang-undang tertentu yang mempunyai acara pidana sendirisendiri seperti di dalam undangundang Tindak Pidana Korupsi.

Pekerjaan Polisi sebagai penyidik dapat dikatakan berlaku di seluruh dunia. Kekuasaan dan kewenangan Polisi sebagai penyidik luar biasa penting dan sangat sulit (Andi Hamzah, 1990:76). Menurut Pasal 14 Undang-Undang Nomor 2 tahun 2002 tentang Kepolisian Negara Republik Indonesia dalam melaksanakan tugas pokoknya Kepolisian Negara Republik Indonesia bertugas untuk melakukan penyelidikan dan penyidikan terhadap semua tindak pidana sesuai dengan hukum acara pidana dan peraturan perundang-undangan lainnya.

Penyidikan sebagai usaha pertama untuk mengumpulkan bukti guna membuat terang suatu tindak pidana sepenuhnya menjadi tanggung jawab Kepolisian Negara. Penyidikan perlu kesempurnaan, karena sebagai. Berhasil tidaknya penuntutan sepenuhnya tergantung dari mutu penyidikan sebelumnya mulai dari tahap pertama sebelum pelimpahan ke tahap penuntutan. Oleh karena itu, terhadap hasil pemeriksaan tersangka dan hasil pemeriksaan tersangka dan bahan pembuktian lainnya, sebelum diserahkan kepada penuntut umum, penyidik wajib secara obyektif menilai bahan pembuktian tersebut atas dasar kebenaran yang sejati mengingat pada asas-asas manusiawi. Tanggung jawab penyidik pada tahap penyidikandiatur dalam pasal 8 jo pasal 75 KUHAP.

Pasal 8 KUHAP
berbunyi: 
(1) Penyidik membuat berita acara pelaksanaan tindakan sebagaimana dimaksud dalam pasal 75 dengan tidak mengurangi ketentuan lain dalam Undang-undang ini.

(2) Penyidik menyerahkan berkas perkara kepada penuntut umum.

(3) Penyerahan berkas perkara sebagaimana dimaksud dalam ayat (2) dilakukan:
a. Pada tahap pertama penyidik hanya menyerahkan berkas perkara;

b. Dalam hal penyidikan sudah dianggap selesai, penyidik menyerahkan tanggung jawab atas tersangka dan barang bukti kepada penuntut umum.

Pasal 75 KUHAP
berbunyi:

(1) Berita acara dibuat untuk setiap tindakan tentang;
a. Pemeriksaan tersangka;
b. Penangkapan;
c. Penahanan;
d. Penggeledahan;

e. Pemasukan rumah;

f. Penyitaan benda;

g. Pemeriksaan surat;

h. Pemeriksaan saksi;

i. Pemeriksaan ditempat kejadian;

j. Pelaksanaan penetapan dan putusan pengadilan;

k. Pelaksanaan tindakan lain sesuai dengan ketentuan dalam Undang-undang ini.

(2) Berita acara dibuat oleh pejabat yang bersangkutan dalam melakukan tindakan tersebut pada ayat (1) dan dibuat atas kekuatan sumpah pejabat.

(3) Berita acara tersebut selain ditandatangani oleh pejabat tersebut paa ayat ditandatangani pula oleh semua pihak yang terlibat dalam tindakan tersebut pada ayat (1).

\section{Ruang Lingkup Psikologi}

\section{A. Pengertian Psikologi}

Dibandingkan dengan ilmu hukum, psikologi merupakan salah satu cabang 
ilmu pengetahuan yang muda.

Ilmu hukum sudah dikenal oleh manusia jauh sebelum tahun Masehi, sejak manusia mulai membentuk kelompok hidup bersama. Psikologi sendiri muncul sekitar abad 19, tepatnya pada tahun 1879 pada saat didirikanya labotarium psikologi yang pertama oleh Wilhelm Wundt di Leipzig, Jerman Barat.

Menurut asal katanya, psikologi berasal dari bahasaYunani:

- Psyhe yang berarti jiwa, dan

- Logos yang berarti ilmu. Secara harfiah psikologi mempunyai arti "ilmu jiwa". Namun demikian, pengertian ilmu jiwa dalam psikologi berbeda dengan pengertian ilmu jiwa itu sendiri. Perbedaannya terletak pada (W. A. Gerungan, 1972: 5-6):

a. Ilmu jiwa:

- Merupakan istilah bahasa Indonesia sehari-hari dan dikenal oleh setiap orang;

- Meliputi segala pemikiran, pengetahuan, tanggapan,khayalan dan spekulasi mengenai jiwa;

- Istilah ilmu jiwa menunjukkan kepada ilmu jiwa pada umumnya.

b. Psikologi:

- Merupakan istilah "ilmu pengetahuan" atau "scientific", yang dipakai untuk menunjukkan kepada pengetahuan ilmujiwa yang bercorak ilmiah;

- Meliputi ilmu pengetahuan mengenai jiwa yang diperoleh secara sistematis dengan metode-metode ilmiah yang memenuhi syarat-syaratnya seperti yangdimufakati sarjana-sarjana 


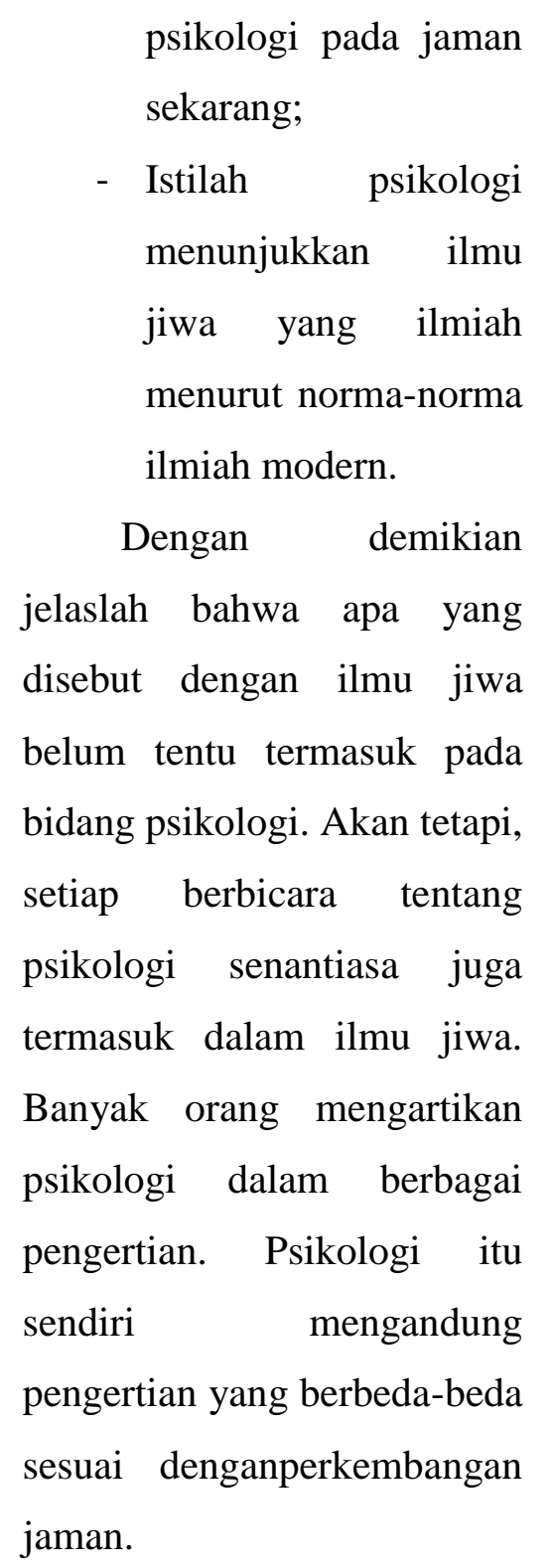

Berdasarkan beberapa pengertian tentang psikologi, disusunlah suatu definisi atau pengertian umum oleh Dr. Sarlito Wirawan, yang merupakan rangkuman dari beberapa pengertian diatas, yaitu (Sarlito Wirawan, 1982:10): “psikologi adalah ilmu pengetahuan yang mempelajari tingkah laku manusia dalam hubungannya dengan lingkungannya."

$$
\text { Berdasarkan }
$$

pengertian psokologi, dapat ditarik kesimpulan bahwa dengan mempelajari tingkah laku manusia kita dapat mengenal seseorang dari perbuatannya baik yang terbuka yaitu tingkah laku yang segera dapat dilihat oleh orang lain, missal makan, minum, memukul, menangis, berbicara dan sebagainya maupun yang tertutup yaitu tingkahlaku yang hanya dapat diketahui secara tidak langsung melalui alat-alat atau metode-metode khusus, missal berpikir, berkhayal, bermimpi, takut dan sebagainya. Sedangkan maksud kata lingkungannya di sini adalah tempat dimana manusia itu hidup, menyesuaikan dan mengembangkan diri sesuai dengan kemampuannya. Definisi Dr. Sarlito Wirawan 
tersebut sesuai dengan pendapat Dr. W.A. Gerungan tentang objek psikologi, yaitu (W. A. Gerungan, 1972: 25): “Objek daripada ilmu jiwa modern ialah manusia serta kegiatan-kegiatannya dalam hubungannya dengan lingkungannya".

Dalam kaitannya dengan aspek-aspek psikologi tersebut, tugas dari seorang psikolog adalah:

a. Mengajar sesamanya;

b. Psikhoterapi Penelitian;

c. Test psikologi;

d. Konsultan badan-badan tertentu, seperi industri, pendidikan, penegakkan hukum.

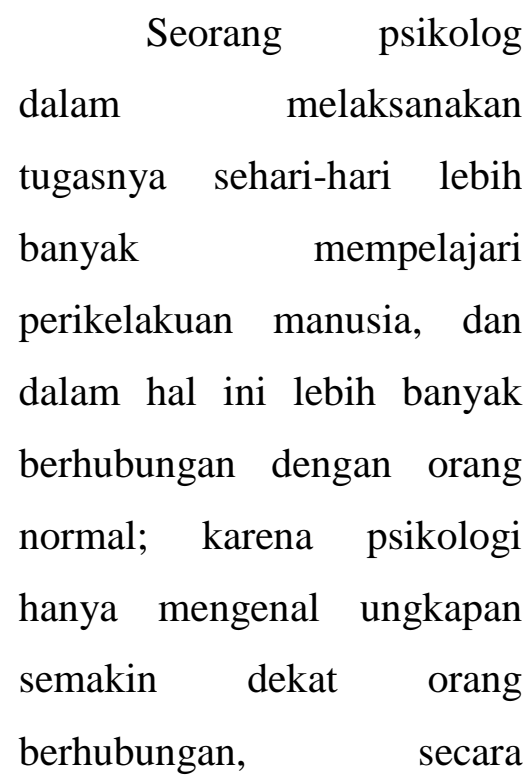

langsung, maka semakin dekat pula hubungan batinnya.

\section{B. Pembidangan dan Metode dalam Psikologi}

Seperti halnya dalam ilmu hukum, psikologi juga dibagi dalam beberapa bidang menurut sifat dan manfaatnya. Pembidangan tersebut meliputi psikologi umum dan psikologi khusus yang terdiri dari psikologi perkembangan, psikologi kepribadian dan tipologi, psikologi sosial, psikologi pendidikan, psikologi diferensial, psikologi patholgi. Di samping itu dikenal pula psikologi klinis, psikologi perusahaan, psyco patologi, psycodiagnostik, serta psikologi kriminil. Dari bidang-bidang tersebut, yang paling banyak berhubungan dan membantu kelancaran tugas penegak hukum umumnya, penyidik khususnya; adalah psikologi kepribadian dan tipologi, psikologi sosial dan psikologi 
kriminil. Psikologi kepribadian dan tipologi merupakan ilmu yang menguraikan struktur dan jenis-jenis dan tipe-tipe kepribadian manusia sebagai suatu keseluruhan. Psikologi social merupakan salah satu cabang ilmu pengetahuan yang menyelidiki proses interaksi antara umat manusia, artinya memeplajari sejauh mana tingkah laku manusia dipengaruhi oleh dan mempengaruhi tingkah laku manusia lain. Sedangkan psikologi krimnal mempunyai tujuan untuk meneliti bahwa (B. Simanjutak, 1980:29): "sebab-sebab kejahatan terletak pada penyimpangan kejiwaan, meneliti relasi watak jiwa dengan bentukkejahatan, serta situasi psikologi yang memotiper tindakan jahat. Disamping itu, juga meneliti aspek psikhis dari para oknum yang terlibat dalam penyidangan (jaksa, hakim, panitera, terdakwa, pemeriksa) dalam hubungannya dengan psikologi sosial".
Disamping itu, untuk dapat lebih mengenal manusia (dari periperlakuan yang tertutup dan terbuka), diperkenalkan beberapa metode dalam psikologi, yaitu (Soerjono Sukamto, 1979:3):

a. Metode ekperimental, bertujuan hanya untuk mencari hukum-hukum saja mengenai berbagai tingkah laku dan kurang memperhatikan perbedaanperbedaan individual.

b. Metode observasi alamiah, bertujuan untuk melakukan pengamatan terhadap situasi yang sudah ada, situasi yang terjadi secara spontan, tidak dibuat-buat sesuai dengan kehendak alam. Hasil pengamatan ini kemudian dicatat dengan teliti untuk kemudian diambil kesimpulan-kesimpulan umum maupun khusus. Hanya yang perlu diperhatikan dalam metode tersebut adalah kita harus menjauhkan sebanyak mungkin kepentingan dan 
minat-minat pribadi kita, agar dapat dibuat kesimpulan yang bersifat objektif.

c. Metode sejarah kehidupan, berdasarkan pada sejarah kehidupan seseorang yang dapat merupakan sumber data yang penting untuk lebih mengenal orang yang bersangkutan. Adapun sejarah kehidupan dapat disusun melalui dua cara yaitu:

- Pembuatan buku harian;

- Rekonstruksi biografi, caranya yaitu data-data tentang riwayat hidup orang yang akan diperiksa dikumpulkan dan disusun menjadi biografi.

Untuk mendapatkan datadata tentang riwayat hidup seseorang sebagaimana tersebut di atas melalui beberapa cara, yaitu:

- Wawancara dengan orang yang bersangkutan, atau;
- Wawancara dengan orang-orang lain yang kenal dengan orang yang akan diperiksa.

d. Metode wawancara, yaitu suatu tanya jawab antara pemeriksa dengan orang yang diperiksa dengan maksud agar orang yang diperiksa tersebut mengemukakan isi hatinya, pendapat-pendapatnya dan lain-lain, hal sedemikian rupa sehingga pemeriksa /penyidik dapat lebih mengenal tentang pribadi orang yang diperiksa.

e. Metode/pemeriksaan psikologis yang dikenel dengan nama "psikotest". Tujuan diadakannya psikotest adalah untuk mengukur dan mengetahui taraf kecerdasan, arah, minat, sikap, struktur kepribadian seseorang.

Dari beberapa metode yang dikemukakan di atas, menurut pengamatan penulis yang paling dianggap cocok diterapkan oleh penyidik dalam 
tugas pemeriksaan/interogasi

tersangkaadalah metode

wawancara.

Dengan

wawancara terhadap tersangka

terjadi hubungan secara

langsung antara penyidik

dengan tersangka sehingga

memudahkan atau melancarkan

komunikasi karena dapat

diadakan pendekatan kejiwaan

secara bertahap.

\section{Hak-hak Tersangka dalam}

\section{Tahap Penyidikan}

Pembahasan tentang hak-

hak tersangka tidak boleh menyimpang dari salah satu asas di dalam hukum acara pidana dalam kaitannya dengan hak-hak tersangka, yaitu asas "presumption of innancence" atau "praduga tak bersalah" sebagaimana ditetapkan dalam pasal 8 Undang-undang Nomor 14 tahun 1974 jo Penjelasan Umum butir 3 KUHAP. Atas dasar asas ini memberi kejelasan pada kita, bahwa setiap orang yang diperiksa pada tingkat penyidikan belumlah dapat dianggap bersalah. Oleh karenanya ia dihadapkan ke pengadilan dengan tujuan untuk didengar keterangannya, sehubungan dengan tindak pidana yang terjadi guna mencari pengakuan dan pelaku tindak pidana.

Pasal $52 \quad$ KUHAP menjelaskan tentang kebebasan tersangka untuk memberikan keterangan pada penyidik. Pasal 52 tersebut mempunyai maksud sebagaimana tersurat dalam penjelasan pasal 52 KUHAP tersebut, yaitu: "supaya pemeriksaan dapat mencapai hasil yang tidak menyimpang dari yang sebenarnya maka tersangka harus dijauhkan dari rasa takut. Oleh karena itu wajib dicegah adanya paksaan atau tekanan terhadap tersangka."

Atas dasar pasal 52 tersebut diatur lebih lanjut tentang hal-hal yang harus diperhatikan dalam pelaksaan tersangka, yaitu:

a. Tersangka didengar keterangannya tanpa adanya tekanan dari siapa pun atau dalam bentuk apa pun (pasal 117 ayat (1)); 
b. Keterangan apa saja yang diberikan oleh tersangka sehubungan dengan tindak pidana yang dipersangkakan kepadanya, penyidik wajib mencatat dalam berita acara pemeriksaan dengan teliti sesuai kata-kata yang dipergunakan oleh tersangka sendiri. Apabila sudah setujui, berita acara tersebut ditandatangani oleh penyidik dan tersangka (pasal 118 ayat (1));

Dengan singkat dapat dikatakan bahwa (Hadari Djinawi Tahir:1981:3): “KUHAP telah menempatkan manusia sebagai makhluk yang berharkat dan bermartabat pada tempat yang luhur. Karena ia memberikan perlindungan yang lebih kokoh kepada warga negara, lebih memberikan jaminan dihormatinya hak-hak asasi manusia daripada ketentuanketentuan sebelumnya berlaku seperti yang terdapat dalam HIR dan RIB”, khusunya yang menyangkut hak-hak tersangka pada tingkat penyidikan.

\section{Metode Penelitian}

Penelitian ini dilaksanakan dengan cara studi pustaka. Adapun lokasi sebagai berikut :

1. Perpustakaan IKIP PGRI Madiun

2. Perpustakaan Prodi PPKn IKIP PGRI Madiun

\section{Fakultas Hukum UNS}

Berdasarkan permasalahan yang hendak dikaji, maka metode yang digunakan dalam penelitian ini adalah metode yuridis normatif. Penelitian normatif berupa penelitian peraturan perundang-undangan, yurisprudensi (Case Law), kontrak dan nilai-nilai hukum yang hidup dalam masyarakat (penelitian hukum empirik). Pendekatan yang digunakan adalah Statute Approach (pendekatan peraturan perundangundangan, yang mengkaji peraturan perundang-undangan, teori serta konsep-kosep hukum yang berkaitan dengan masalaha yang diteliti.

Dalam penelitian ini peneliti masih menggunakan sumber tertulis sekunder. Bahan hukum primer dapat berupa peraturan perundang- 
undangan yang terkait dengan masalah yang dibahas dalam penelitian ini. Sedangkan bahan hukum sekunder adalah bahan hukum yang memberikan penjelasan terhadap bahan hokum primer seperti buku literatur, majalah/ jurnal dan tulisan artikel para ahli.

Pengumpulan data dilakukan dengan inventarisasi peraturan perundang-undangan yang berkaitan dengan penelitian selanjutnya dilakukan pula inventarisasi data yang bersumber dari buku-buku, lieratur, dokumen resmi, karya tulis, dan hasil-hasil penelitian yang berkaitan. Dalam penelitian ini, teknik analisis data yang digunakan adalah analisis dengan penafsiran kualitaif dan ditampilkan dalam uraian deskriptif analisis.

\section{Hasil Penelitian}

Fungsi dan peranan psikologi dalam bidang hukum, menurut Farrington dan Hawkins (dalam Sarlito, 1982:20) berpendapat bahwa: "peranan psikologi dalam hukum dapat dibagi dalam tiga jenis, pertama psikologi dapat digunakan untuk menguji kebenaran pra- anggapan yang digunakan dalam hukumitu sendiri, kedua digunakan dalam proses hukum dan ketiga digunakan dalam sistem hukum itu sendiri."

Sedangkan fungsi psikologi menurut Sarlito Wirawan (1982:22) adalah: "seperti ilmu-ilmu sosial lainnya, psikologi mempunyai dua fungsi yaitu, pertama adalah fungsi pengertian (understanding) dan kedua fungsi peramalan (prediction)".

Penerapan psikologi dalam hukum yang didasarkan pada fungsi psikologi tersebut pada dasarnya adalah berkaitan dengan hak-hak asasi tersangka sebagai pihak yang sedang dibatasi kebebasannya.

Manusia adalah subyek yang sekaligus obyek. Menyimak definisi psikologi menurut Sarlito Wirawan, menjadi jelas bagi kita bahwa sebenarnya manusialah yang paling berkepentingan dengan psikologi. Manusialah yang paling membutuhkannya dalam berbagai segi kehidupan, baik dibidang sosial, ekonomi, politik, budaya dan hukum. Mengingat hukum itu sendiri juga merupakan perilaku dipandang dari 
segi tertentu dan standart dari perilaku, maka psikologi dapat diterapkan dalam penyelesaian suatu tindak pidana.

Hal ini dapat dilihat dari peranan psikologi dalam hukum point kedua, yaitu dalam proses hukum. Yang dimaksud dengan proses hukum disisni menurut Farrington dan Hawkins (dalam Sarlito, 1982:21) adalah proses pemeriksaan atau interogasi tersangka pada tingkat penyidikan. Peranan psikologi sangat besar peranannya dalam proses ini, karena psikologi melihat latar belakang tingkah laku dan perbuatan individu yang diperiksa. Penyidik yang menguasai, minimal mengetahui sedikit psikologi, dapat dengan mudah mengenal watak, pribadi tersangka, sehingga dapat ditentukan teknik-teknik pendekatan yang cocok untuk keberhasilan pemeriksaan yang berlangsung secara manusiawi.

Tidak dapat dipungkiri bahwa dalam proses pemeriksaan tersangka seorang penyidik harus banyak menggunakan menerapkan teknik personal approach. Dengan pendekatan yang subyektif, penyidik

dapat mengetahui dan menggambarkan bagaimana kepribadiannya, di mana letak kelebihannya dan kelemahannya. Ketika mencari keterangan dari tersangka seorang penyidik perlu menerapkan salah satu atau beberapa dari bidang-bidang yang terdapat dalam psikologi yang dianggap paling tepat untuk membantu kelancaran tugasnya, seperti penerapan dibidang psikologi kepribadian atau tipologi apabila melihat tujuan dari psikologi kepribadian atau tipologi adalah untuk melihat mempelajari kepribadian, ciri-ciri, tipe-tipe seseorang.

Seseorang, di dalam menentukan kehendaknya sangatlah ditentukan oleh adanya keserasian antara pikiran dengan perasaan. Pikiran dan perasaan ini dalam perkembangannya akan mempengaruhi segala perbuatan dan tingkah lakunya sehari-hari. Penerapan di bidang psikologi kepribadian dan tipologi saja sebenarnya belumlah sempurna, karenanya perlu di bantu dengan penerapan di bidang psikologi yang 
lain seperti psikologi sosial, psikologi kriminil dan lain sebagainya. Manusia adalah subyek yang tidak lepas dari peranannya sebagai makhluk sosial. Jadi kaitannya dengan pemeriksaan tersangka dengan penerapan beberapa bidang psikologi, diharap penyidik akan memperoleh pengertian mengapa seseorang atau tersangka tersebut melakukan tindak pidana tertentu.

Kelancaran dalam menarik keterangan dari tersangka adalah tergantung dari kemampuan dan kepandaian penyidik dalam menerapkan taktik dan teknik penyidikan. Oleh karenanya,penguasaan terhadap bidang- bidang dalam psikologi tersebut di atas dilengkapi dengan pengusaan dalam bidang wawancara, karena metode tersebut ikut memegang peranan penting dalam kelancaran pemeriksaan tersangka. Dengan teknik-teknik wawancara, terutama keahlian dalam menyusun pertanyaan-pertanyaan yang diajukan, merupakan alat bantu yang sangat penting. Dengan alat ini bisa diadakan pendekatan dengan mengajak tersangka berdialog, berdiskusi, mengajukan pertanyaanpertanyaan dengan santai tetapi lancar sehingga tersangka maupun penyidiktidak akan mudah terpancing emosi. Di dalam pemeriksaan, sringkali penyidikmemperingatkan tersangka, karena dinilainya tersangka berbelitbelit dalam menyampaikan keterangannya. Dalam keadaan bagaimanapun penyidik harus bisa menahan emosi, bisa menahan kesabaran. Dengan keabaran yang tinggi bukan berarti mengalah, tetapi justru disisnilah arti pentingnya pendekatan oleh penyidik terhadap tersangka dengan alat bantu psikologi.

Seorang penyidik harus berbicara sedikit, tegas, terang tetapi jangan meninggalkan kesopanan dan keramahan, bersikap kekeluargaan, ramah dan menarik. Apabila tersangka mempunyai perasaan takut, harus bersifat membimbing dan terhadaptersangka yang sombong, lebih baik memuji dan menyanjungnya. Keadaan tersebut akan membuat tersangka merasa diperhatikan sebagai subyek yang 
mempunyai hak dan kewajiban. Dari situasi yang baik inilah, tersangka akan memberikan jawaban atau keterangan yang sebenarnya dan sejujurnya. Pendekata secara psikologis sebagaimana di uraikan di atas, tidak lepas dari pendapat Charles R. Swansons Jr., bahwa ada dua prinsip yang dapat diterapkan agar seseorang mau mengaku dalam suatu kejahatan atau tindak pidana,yaitu (Chales R. Swansons, $\mathrm{Jr}$, Criminal Investigation (Santa Monica, California; Goodyear Publising Company Inc., 1977) halaman 170):

“... Firs, there are those guilty parties who seek some psychological motive for "fetting it off their chest." The second category is comprised of those who are not guilty but who act under some urge to confess...."

Jadi, prinsi-prinsip tersebut di atas dapat berlangsung dengan lancar dikarenakan adanya pemakaian penerapan psikologi dalam taktik dan teknik penyidikannya, sehingga seseorang mau memberikan keterangan aau mengakui.

Berdasarkan pada hasil penelitian dapat disimpulkan:
1. KUHAP yang berlaku sekarang sangat menjunjung tinggi harkat dan martabat manusia, khususnya tersangka dan terdakwa. Keadaan ini berbeda jauh dengan pemuatan hak asasi manusia sebagaimana di atur dalam HIR. Dengan adanya perubahan dalam peenerapan hak asasi manusia, memberikan pengertian bagi kita, bahwa telah terjadi perubahan yang sangat fundamental dalam proses peradilan, khususnya dalam tahap penyidikan yang berkepentingan langsung dengan hak asasi tersangka. Mengingat yang dihadapi langsung oleh penyidik adalah pribadi yang mempunyai prisip/pendapat dan pemikiran "body and mind" sebagai subyek hukum maka tersangka sebagai individu juga mempunyai hak untuk diperhatikan dan dilindungi sesuai dengan haknya dalam rangka pengeterapan dan penghormatan harkat dan martabat manusia.

2. Sudah bukan jamannya lagi apabila dalam pemeriksaan tersangka diterapkan cara-cara 
kekerasan yang tidak manusiawi. Keterangan tersangka memang sangat diperlukan sekali, tetapi tidak berarti harus diperoleh dengan jalan pintas yang kasar. Untuk mendapatkan keterangan yang jujur dan benar, seorang penyidik dapat menerapkan salah satu bidang ilmu bantu dalam rangka penegakkan hukum, yaitu psikologi. Psikologi lebih berpijak pada pengetahuan tentang manusia, khusunya tentang perilaku dan perbuatan manusia dalam hubungannya dengan lingkungannya. Dengan dibantu psikologi, dapatlah seorang penyidik memperoleh atau "mengorek" keterangan dari tersangka dengan mudah, karena telah dapat dilakukan pendekatan pribadi (personal approach) yang manusiawi. Dengan demikian penggunaan psikologi dalam pemeriksaan tersangka merupakan satu tahap langkah kemajuan bagi dunia penegak hukum. Jadi peranan psikologi dalam hukum mempunyai tujuan yang positif, yakni disamping untuk menjaga harkat dan martabat tersangka pada tingkat penyidikan, juga demi efektifitas pemeriksaan.

Berdasarkan simpulan hasil penelitian tersebut, maka peneliti memberikan saran sebagai berikut:

1. Berpangkal dari tugas Polisi yang semakin berat dikaitkan dengan pengeterapan hak asasi manusia pada pemeriksaan tersangka pada tingkat penyidikan, masih banyak kekurangan-kekurangan yang harus dipenuhi secepatnya. Bahkan Polisi sebagai penyidik tunggal perlu dibekali dan ditingkatkan pengetahuannya, baik di bidang hukum maupun di bidang ilmu bantu lainnya, khususnya psikologi demi kelancaran tugasnya sebagai penyidik, sehingga diperoleh tenaga penyidik yang trampil dan qualified dalam pelaksanaan tugasnya.

2. Bahwa perlu diadakan kerjasama antara aparat atau instansi penegak hukum, khususnya Kepolisian Negara Republik Indonesia dengan pihak-pihak yang berkecimpung 
dalam psikologi, yaitu para psikolog.

\section{Daftar Pustaka}

Andi Hamzah. 1990. Pengantar Hukum Acara Pidana Indonesia., Jakarta:

Ghalia Indonesia

Charles R Swansons, Jr. 1977. Criminal Investigation. Santa Monica California: Goodyear Publishing Company.

Departemen Kehakiman. 1982. Pedoman Pelaksanaan KUHAP. Gerungan, W.A. 1972. Psycology Sosial. Bandung:Eresco R.Soesilo. 1980. Taktik dan Teknik Penyidikan Perkara Kriminal. Bogor: Politea.

Sarlito Wirawan. 1982. Pengantar Psikologi. Jakarta: Bulan Bintang. 1982. Psikologi Dalam Hukum. Jakarta: Bulan Bintang.

Soekanto, Soerjono. 1979. Beberapa Catatan tentang Psikologi Hukum. Bandung: Alumni.

Simandjuntak. 1980. Kriminologi dan Patologi Sosial. Jakarta: Tarsito.
Soesilo, R. Taktik dan Teknik Penyidikan Perkara Kriminil. Bogor: Politea.

Undang-Undang Nomor 2 Tahun 2002 tentang Kepolisian Negara Republik Indonesia. Undang-Undang Nomor 6 Tahun 1982 tentang Hukum Acara Pidana.

Undang-Undang No.17 Tahun 2007 tentang Rencana Pembangunan Jangka Panjang Nasional (RPJMN) 2005-2025. 